\title{
Beliefs About The Nature of Mathematics, As A Subject on Senior Secondary School Student's Academic Performance in Madagali L. G. A., Adamawa State
}

\author{
Marcel P. Agah
}

\begin{abstract}
This paper surveys students' beliefs on the nature of mathematics as to whether it is the cause of their poor performance in mathematics at the secondary school level in Madagali local Government area of Adamawa State. The population consists of 1,062 public senior secondary students in Madagali L. G. A. of Adamawa State. One hundred and thirty senior students were randomly sampled and used for the study. The instruments used for this study was a questionnaire tagged students opinion questionnaire (SOQ) and students third term examination results. The instrument was validated and pilot tested with reliability coefficient of 0.73 . One research question and a hypothesis were formulated and tested at 0.05 . Data were analyzed using mean and standard deviation for research question and hypothesis was tested using Pearson's $r$ statistic. Result revealed that student's poor performance in mathematics was as a result of their poor perception of the nature of mathematics. Based on the findings, it was recommended among others that, teachers should endeavour to use the available methods or ways of simplifying problems to the understanding of the students. To that extent, teachers should relate abstract ideas or concepts to real life activities.
\end{abstract}

Index Terms - Nature of mathematics, academic performance, student's perception, Madagali Local Government.

\section{INTRODUCTION}

Beliefs play great role in mathematics learning and teaching. The learning outcomes of students are strongly related to their beliefs and attitudes about mathematics (Furinghetti \& Pehkonen, 2000). Therefore, Students' beliefs about the nature mathematics and mathematics learning can have a substantial impact on their interest in mathematics, their enjoyment of mathematics, and their motivation in mathematics classes.Thus assessing or evaluating of students' mathematical knowledge must be made in awareness of their beliefs. Educational system throughout the world place high importance on the teaching and learning of mathematics, and mathematics is seen as contributing to the intellectual development of individual students. The use of mathematics to man therefore is as diverse as there exists human endeavours. But almost no one today in Nigeria concern with the teaching of mathematics at any stage, from infants upwards and, particularly at secondary level, can

Marcel P. Agah, Department of science education, faculty of education, adamawa state university, mubi, Nigeria honestly say to himself that all is well with the teaching of mathematics. Hence, today there are many students who abandon the secondary school with a dislike for mathematics and most people agreed that a requirement for success in teaching mathematics is knowing mathematics first.

Government, employers of labour, parents and teachers have expressed their concern about the fact that large number of students after secondary school course is unable to perform many of the simple arithmetical and mathematical operations needed in their everyday life. One reason we can advance, is that majority of students never get thorough understanding of real meaning of mathematics concepts. Eventually they develop a common attitude, "get the examination over" after which forget about mathematics.

Mathematics is generally regarded as difficult subject among sciences everywhere, but very little is being done to alter this state of affairs. Agah (1999), noted that some student use to make comments like, I can't believe it, even looking at those fractions my stomach turns. Oh my God, I am going to make a fool of myself - or be found out when confronted with mathematics problems. Huntley et al, (2000) says that, in some cases, these students become hostile, cut class, refuse to work, annoy other students and lash out with disruptive behaviuor such as jostling each other, making obscene gestures, throwing objects or makes remarks like;

- I don't understand any of this junk

- You are confusing me as usual

- I hate those stupid fractions what good are there anyway?

- I am gonna burst him right here.

- I am not gonna do it.

- Some crude stole my paper etc.

Mathematics, with its abstract symbolism, its logical structures, its wide application, has unique learning problems. At one extreme, it involves learning simple skills, calculation, facts and procedures where memory practices are most essential. At the other extreme, the analysis of a problem, the proof of a theorem, the application of a generalization, the building of a mathematical structure, these require a high level of creative thinking. The teacher of Mathematics therefore, must know when and what concepts to teach, when and why students are having difficulty, how to make concepts meaningful, when and how practice skills and how to stimulate productive thinking.

Any participant in the West Africa Examination Council (WAEC) marking exercise for the SSCE Examinations in 
mathematics may agree with this assertion that mathematics in this country is in a "sorry state" (Agah, 2008). Many things both funny and at times annoying are seen in student's mathematics answer script. Very many of the students waste their time in the examination doing nothing or drawing and painting irrelevant diagrams. Some even wrote to demand the examiners to score them marks for such diagrams. Many others too submit just blank scripts with covering notes requesting the examiner in God's name to temper justice with mercy on blank sheets. Others do make statements like;

Do well to me; God will do well to you. In God's name, I want you to help me.

What good is this mathematics? I am not the type for mathematics etc.

In fact, one has to be at WAEC marking centers to notice the seriousness of the problems of mathematics education in this country. Therefore, the alarming poor state of mathematics education in the Nigerian secondary schools system does not need any documentation.

However, an examination of senior school certificate summary result organized by WAEC from 2000 to 2012 is as shown in table 1;

Table 1: Summary of Mathematics Result by WAEC 2000 - 2012

\begin{tabular}{lll}
\hline Years & $\begin{array}{c}\text { Percentage pass with } \\
\text { credit and above }\end{array}$ & $\begin{array}{l}\text { Percentage with } \\
\text { pass and below }\end{array}$ \\
\hline $\mathbf{2 0 0 0}$ & 32.81 & 67.19 \\
$\mathbf{2 0 0 1}$ & 36.55 & 63.45 \\
$\mathbf{2 0 0 2}$ & 34.50 & 65.50 \\
$\mathbf{2 0 0 3}$ & 36.91 & 63.09 \\
$\mathbf{2 0 0 4}$ & 34.52 & 65.42 \\
$\mathbf{2 0 0 5}$ & 35.55 & 64.45 \\
$\mathbf{2 0 0 6}$ & 39.92 & 60.08 \\
$\mathbf{2 0 0 7}$ & 15.56 & 84.44 \\
$\mathbf{2 0 0 8}$ & 23.00 & 77.00 \\
$\mathbf{2 0 0 9}$ & 31.00 & 69.00 \\
$\mathbf{2 0 1 0}$ & 25.90 & 74.01 \\
$\mathbf{2 0 1 1}$ & 14.8 & 89.9 \\
$\mathbf{2 0 1 2}$ & 62.00 & 37.00 \\
\hline
\end{tabular}

Source: WAEC Statistics Division

Clearly the current poor state of mathematics education in the Nigerian school system is alarming, worrying and disturbing to all those concerned about the future of Nigeria in the modern age. The problem is like a serious endemic disease that requires an equally serious and urgent surgical operation.

Agah (2005), lamented that the main cause of this indescribably poor performance of students could be traced to the candidate themselves who were care - free, unconcerned and showed uncooperative attitudes.

This deplorable state of secondary school mathematics education in the contemporary Nigerian educational system is, and will continue to be a major deterrent not only to the general scientific and technological development of the nation, but also to the realization of the economic goals of the country. These have therefore posed a serious problem for the mathematicians and other mathematics lovers in Nigeria. Many questions have been asked about these conditions of students' poor performance in mathematics such like, attitude of the students towards the subject, teacher's attitude towards mathematics, teacher's method of teaching mathematics, materials for teaching mathematics, parent's attitude toward mathematics, government policy. While, this paper focused on the nature of mathematics as to whether be a factor that affects student's poor performance in mathematics.

Statement of the Problem: The success of teaching and learning of mathematics depends to a large extent on teacher's own knowledge of the content and ability to adequately deliver the instruction to the students. Though a number of factors may hinder effective dissemination of knowledge as students understanding of the content such factors may be teacher's qualification, experiences, and student's attitude among others. Thus the present work focuses on the students' beliefs of the nature of mathematics content as affecting the academic performance of students in mathematics.

Purpose of the Study: The purpose of this work is to find out the students opinion on the nature of mathematics as whether it affects their academic performance.

Research Question: Does the nature of mathematics influence students performance in mathematics examinations?

Research Hypothesis : There is no significant relationship between students' perception of the nature of mathematics and their academic performance.

Significance of the Study: The study is significant to students whose interest in the learning process is of paramount importance to teachers and who are likely want to know that their standard of performance in mathematics depend largely on their personal perception of the nature of mathematics.

Research Design: This work is a survey study set out to investigate the effect of the nature of mathematics and students' academic performance.

Population and Sampling: The population of this study consists of 582 senior secondary school students in Madagali Local Government area of Adamawa State. The sample of this study consisted of 130 students randomly selected from six (6) senior schools in the study area based on intact classes through simple random sampling. 
Instrumentation: Two research instruments used for this study include: student's opinion questionnaire (SOQ). The questionnaire is made up of two sections. Section A dealt with the demographic variable of the respondents while section B consisted of 10 items; and students' third time examination scores.

Validation and reliability of the instruments: The instrument, student opinion ouestionnaire (SOQ) was validated by three experts after which the items decreased from 15 to 10 . The reliability coefficient was calculated using Chronbach - alpha which gave an index of 0.73 .

Method of Data Collection and Analysis: The instruments for Data collection was students opinion questionnaire (SOQ) which elicited information from students view on the nature of mathematics, as it relates to their performances and students third time examination results. The scoring of the students responses, adopted Likert scale of: Strongly agree S.A - 4 points, Agree A - 3 points, Disagree D -2 points and Strongly Disagree S.D -1 points.

The research questions were answered using means and standard derivations, while hypothesis was tested using Pearson's' r statistic. Any response with a mean of 2.5 or above was accepted and those below were rejected.

\section{RESUltS}

Does the nature of mathematics influence student's performance in mathematics examinations?

Table 2: Means and standard deviation of student's perception on the nature of mathematics.

\begin{tabular}{|c|c|c|c|c|}
\hline S/No & Items & Mean & Sd & Remark \\
\hline 1. & mathematics is the most difficult subject & 3.56 & 1.59 & Accept \\
\hline 2 & Don't understand the languages of math & 2.70 & 2.68 & Accept \\
\hline 3 & There are just too many formulas to remember & 2.91 & 1.50 & Accept \\
\hline 4 & Math is not an interesting subject & 3.72 & 1.79 & Accept \\
\hline \multirow[t]{2}{*}{5} & Steel a sense of insecurity when attempting math problems & & & \\
\hline & & 1.97 & 2.53 & Reject \\
\hline 6 & It takes a long time to solve math problem & 3.74 & 1.95 & Accept \\
\hline \multirow[t]{2}{*}{7} & I am not the type that will do well in mathematics & & & \\
\hline & & 2.02 & 2.52 & Reject \\
\hline 8 & Taking math is a waste of time & 2.84 & 2.62 & Accept \\
\hline 9 & I have never like mathematics & 3.84 & 1.44 & Accept \\
\hline \multirow[t]{3}{*}{10} & It makes me nervous to even think about mathematics & & & \\
\hline & & 3.03 & 1.73 & Accept \\
\hline & Grand Mean & 3.03 & & Accept \\
\hline
\end{tabular}

Table 2 reveals the students' opinion on the nature of mathematics as a factor militating against their poor performance in mathematics. Except items 5 and 7 which stated that "I feel a sense of insecurity when attempting mathematics problems" and "I am not the type that will do well in mathematics" respectively, all other remaining items were accepted by the respondents (students) as factors that are responsible for their poor academic performance in mathematics.

Research Hypothesis: There is no significant relationship between student's perception on the nature of mathematics and their academic performance.

Table 3: Mean score of students' third term examination and their responses on the student's opinion questionnaire (SOQ)

\begin{tabular}{lllllll}
\hline Subject & $\mathbf{N}$ & $\mathbf{X}$ & $\mathbf{d f}$ & Pearson $\mathbf{r}$ & $\mathbf{t}_{\text {cal }}$ & \\
\hline SOQ & 130 & 32.07 & 128 & 0.63 & 4.43 & 2.50 \\
Exam & 130 & 31.05 & & & & \\
\hline
\end{tabular}

Table 3 shows that the mean scores of students in their opinion to the nature of mathematics are 32.07 and their third term exam is 31.05 respectively and the correlated $r$ is 0.63 . Since the $\mathrm{t}$ - calculated of 4.48 is greater than $\mathrm{t}$ - tabulated of 2.50 , hence the null hypothesis is rejected.

\section{DISCUSSION}

The study investigated the student's opinion on the nature of mathematics vis-à-vis their performance in the classroom. One research question was answered and one hypothesis was also tested. Students have accepted that their poor performance in mathematics was as a result of the difficult nature of mathematics. The research hypothesis revealed that there is a significant relationship between student's opinion and their performance in mathematics. This findings agreed with the earlier studies related to this research. Laurie (1984), Huntley et al (2000). in their findings, some people viewed mathematics as a completely abstract construction. But what of the role mathematics has played and will continue to play in the development of mankind? The way mathematics is approached in the classroom and the way it is taught tends to give the subject as not related to ordinary life because of the negative and different approaches to it. Basic ingredients in a desirable classroom atmosphere include teachers' interest in mathematics and a concern for students as persons and their 
progress should be encouraged.

It should be noted that, teachers are not always to be held accountable when students are unsuccessful in learning subject matter. Lawyers, psychologists and others in the helping professions cannot always be blamed when their services fail to meet with success for a client. Sometimes circumstances prevent even the best treatment from resulting in desirable outcomes. Similarly, a teacher's strategy may represent the best that one can reasonably expect but it may not suffice for observable student progress. Particularly, when students believed that they cannot coop with mathematics because of its abstract nature.

\section{RECOMMENDATION}

Teachers should Endeavour to use the available methods or ways of simplifying problems to the understanding of the students. To that extent, teachers should relate abstract ideas or concepts to real life activities.

\section{REFERENCES}

[1] Agah, M. P. (1999). Senior Students Perception of their Poor Performance In Mathematics in Mubi Educational zone Adamawa State. An Unpublished Masters Dissertation submitted to the Department of Science and Technology Education, University of Jos, Plateau State, Nigeria.

[2] Agah, M. P. (2008). Challenges of mathematics in Economic Development in the Twenty- First Century Implications for Tertiary Education. Dulbuni Journal of Education Research (JUJER). 1(3) $46-$ 57.

[3] Chief Examiners Report (2000-2010). The West African Examinations Council Senior School Certificate Examination May/June Series.sFuringhetti, F. \& Pehkonen, E. (2000). A comparative study of students' beliefs concerning their autonomy of doing mathematics. NOMAD 8(4), 7-26.

[4] Huntley, M. A., Rasmussen, C. L., Villarubi, R. S., Sangtong, R. S., Sangtong, J., \& Fey, J. T (2000). Effects of Standards-based mathematics education: A study of the Core-Plus Mathematics Project algebra and functions strand. Journal for Research in Mathematics Educati on, 31, 328-361

[5] Laurie, B. (1984). Do you panic about Mathematics? Coping with Maths Anxiety. Heinemanu Educational Books Ltd London.

[6] Salman, M.F. (2005). Teacher identification of the difficulty level of topics in the primary school mathematics curriculum in Kwara State. Abacus Journal of mathematical Association of Nigeria. 30 (1) $20-29$ 